\title{
Bio-chemical methods in wasteprocessing
}

\author{
Maria Kušnierová, Vladimír Šepelák, Ol'ga Šestinová \\ The Institute of Geotechnics of the Slovak Academy of Sciences, Watsonova 45, 04353 Kosice, Slovak Republic, \\ e-mail:kusnier@saske.sk
}

\begin{abstract}
The mineral biotechnologies, the domain of which is primary raw material processing, are increasingly diversifying into some metallurgical areas. The presented results of the research carried out with metallurgical wastes from aluminium production, lead waste remaking and desulphurization zinc-ferrite-based sorbents regeneration prove the possibility of the use of bio-chemical methods. The results obtained and the proposed technologies applying bio-chemical processes enable a complex processing and use of waste sludge from aluminium production and the use of wastes from matte-based copper production for the production of hematite pigments. The use of microorganisms in the desulphurization sorbent regeneration processes allows to increase sorbent's efficiency and its repeated recycling.
\end{abstract}

Keywords: Bioleaching metallurgical wastes, pigment, sorbent.

\section{INTRODUCTION}

Biotechnologies are considered as one of the basic pillars of $21^{\text {st }}$ century development and they are not developing and will not be developing only in the traditional areas like medicine, food-processing and pharmaceutical industries. In the recent past the diversification of biotechnologies into heavy industry seemed absurd, but the study of exogenous natural processes brought a range of information, which initiated the establishment of a specific branch "mineral biotechnologies", which include oxidation and reduction processes of inorganic substrates with the help of autochthonous and modified chemolithotrophic microorganisms or their metabolites. As the composition of many metallurgical wastes is very close to that of primary raw materials, we considered it useful to study the possibility of the use of these bio-chemical processes in this area. The research was focused on the existing ecological load of metallurgical industry, which is produced during:

1 - bauxite processing in ZSNP a.s. in Žiar nad Hronom,

2 - lead waste remaking in Kovohuty Př́bram,

3 - regeneration of desulphurization ferrite-zinc-based sorbents of combustion products.

The performed research confirmed the possibility of the application of bio-chemical processes and in some cases resulted in the presentation of proposals of industrially applicable procedures.

\section{RESULTS}

1 - Biological and chemical treatment of waste sludge from aluminium production.

Except for some single cases, waste sludge from aluminium production is not currently used and represents a serious environmental danger. Depending on the geographical location of individual production plants, waste sludge is either dumped directly in the sea or stored on the man-made waste disposal sites occupying vast soil areas. The individual sludge boxes occupy on average $900-1300$ hectares. In Slovakia there are about 10000000 tonnes of waste dumped next to production plants. The first attempts at a complex use of sludge from aluminium production date back to the period before the World War II. Up till now there has been a number of research projects focused on the possibility of reuse of utility elements $(\mathrm{Fe}, \mathrm{Al}, \mathrm{Ti}, \mathrm{Ga})$ and on the massive direct use of this material in the production of various kinds of construction materials, ceramic materials, pigments and fillers. Several different technically interesting technologies have been developed, but in most cases, they were not viable due to economic reasons. A lot of procedures showed to be partially viable, e.g. in the production of cement, ceramic floor tile materials, bricks, fillers and iron production charge additives providing the receiving plants are situated close to the source of produced waste. From the relative area of the use of bio-chemical processing of this type of sludge it is possible to use the results available from the research of chemolithotrophic bacteria Thiobacillus ferrooxidans, carried out by Hungarian researchers in the form of pilot operation experiments, which were aimed at obtaining $\mathrm{Na}_{2} \mathrm{O}$ and $\mathrm{Al}_{2} \mathrm{O}_{3}$ and achieving relatively good yield parameters, but this procedure has not dealt with the issue of detoxication, processing and the use of large quantities of acid sludge with $\mathrm{Fe}$, Ti and $\mathrm{V}$ concentrations $\mathbf{s}^{\mathbf{1}, 2,3}$.

The set of technological knowledge on the possibility of a complex use of sludge from aluminium production has been extended with the results of the study carried out in our institution focused on the usability of combined bio-chemical procedures based on the application of selected species of chemolithotrophic microorganisms ${ }^{4}$, which resulted in the technological procedure design protected by the patent of the Slovak Republic.

The most significant changes have been observed during the application of a leaching agent based on metabolic products of microorganisms, which are considered to be involved in the proposed procedure. The full decomposition of original waste sludge components was achieved by sludge processing applying an optimised procedure, while it consequently and partly parallelly came to a gradual precipitation of autigenous compounds. The designed and by the laboratory model tested technology of bio-chemical processing of sludge from aluminium production (Figure 1) enables to transform the phase composition of sludge and to incorporate the majority of elements into the forms of compounds industrially usable in the building industry and production of plastic materials.

The designed procedure represents a waste free technology with a high degree of recycling of technological extraction media. The presented technology is protected by the Bureau of Industrial Property of the Slovak Republic. It allows to 


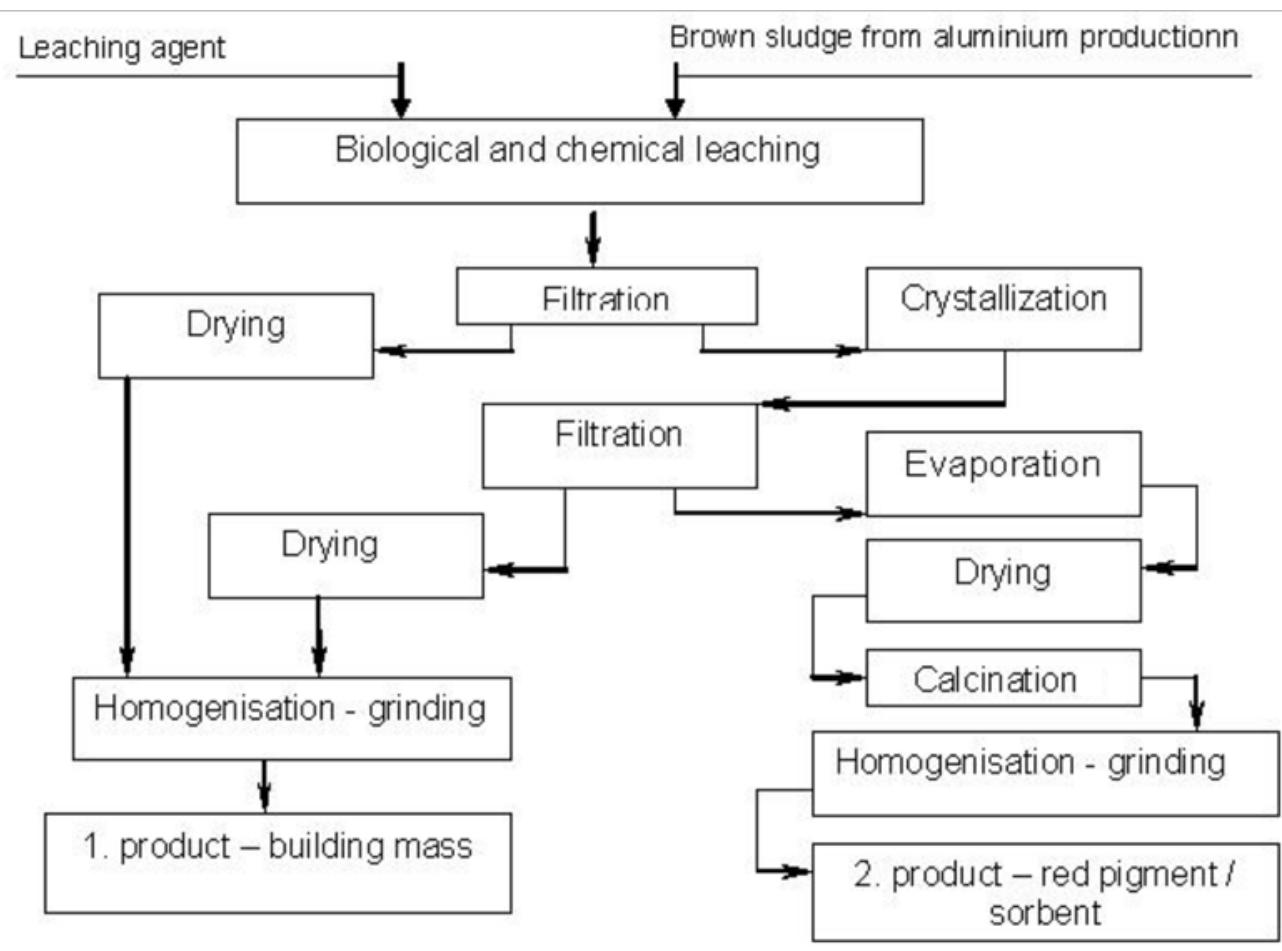

Figure 1. Technology of the complex treatment of waste sludge from the aluminium production

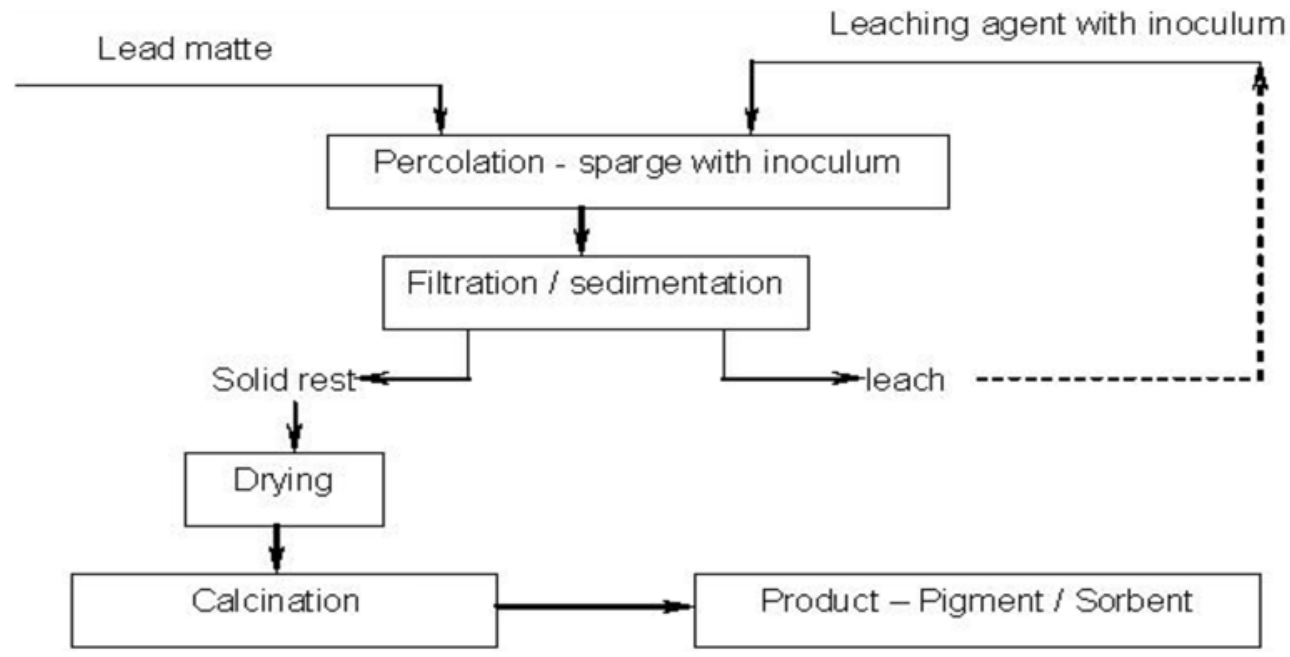

Figure 2. Technology of the treatment of lead matte

process sludge in the form of two to four final products. The simplest two-product variant allows to process sludge into hemihydrate and red pigment.

After the corrective treatment of radioactive properties, hemihydrate can be used in the complex gypsum plasterboard program. (In Slovakia this program is currently fully covered by import and its introduction in Slovakia in cooperation with the corrective anhydrite material producers could contribute to the creation of jobs). On the basis of preliminary tests, red pigments can be used in plastic material processing. The world demand for quality red pigments is not sufficiently satisfied by industrial production and it is expected that they will represent a profitable article on the commodity market ${ }^{5}$.

2 - Bio-chemical preparation of hematite pigment/sorbent from lead matte.

The major element of lead matte is Fe, which is bound mainly in sulphidic form of pyrrhotine (FeS). Matte contains admixtures like $\mathrm{Zn}$ and $\mathrm{Pb}$, which are also bound in sulphidic form.
The bio-chemical oxidation processes are industrially applied in the primary sulphidic ore processing and that is why there was a realistic assumption that it would be possible to apply these methods in the lead matte processing. The research confirmed that the application of a mixed culture of thionic bacteria Thiobacillus ferrooxidans and Thiobacillus thiooxidans is optimal for matte processing. ${ }^{6}$

The product of the matte biological-chemical leaching (Figure 2) is a fine ochre coloured material whose chemical composition and grain size composition correspond to the produced brown pigment.

The calcination of the obtained bacterial leached materials enable to prepare a red commercially utilizable pigment from waste matte whose demand in the world markets exceeds the present production.

The bio-chemical leaching processes with uncontrolled kinetics and a minimal degree of optimisation of sprinkling can also proceed "in situ" with very low economic costs. 
3 - Biological - chemical regeneration of desulphurization sorbents based on zinc ferrite

For the desulphurization and decarbonization of these emissions more commercial technological methods have been developed, to which the utilization of solid sorbents (filters) based on the zinc ferrite also belongs.

The phase composition of amortized (passived) sorbents shows the presence of sulphidic and carbidic structures located mainly on the surface of particles of zinc ferrite. They became inactive and further utilization is constrained to their regeneration. In relation with the most effective methods of manifold recycling of sorbents, several methods of their regeneration were studied.

The literature shows two methods of the regeneration of sulphatizing sorbents based on zinc ferrite. The first method commercially used, is oxidising pyrolysis of sulphides ${ }^{7}$. In this process are the sulphidic structures in dependence on the temperature of the oxidising rousting transformed step by step at the first stage to the sulphates and at the second stage which corresponds to the temperature of sulphates decomposition (in the temperature range from 480 to $600{ }^{\circ} \mathrm{C}$ ) to the oxides, according to the equations (1) and (2):

$2 \mathrm{FeS}+3.5 \mathrm{O}_{2} \longrightarrow \mathrm{Fe}_{2} \mathrm{O}_{3}+2 \mathrm{SO}_{2}$

$\mathrm{ZnS}+1.5 \mathrm{O}_{2} \longrightarrow \mathrm{ZnO}+\mathrm{SO}_{2}$

The second method of the regeneration of desulphurization sorbents which is introduced by $\mathrm{Sakao}^{8}$, is based on the principle of pressure leaching of $\mathrm{ZnS}$ in water environment at the temperature over $550^{\circ} \mathrm{C}$. This method is described by the equation, almost identical with the Eq.

The commercially available technologies of sulphides processing and treatment (as sources of colour and rare metals) have nowadays started with the utilization of biological-chemical processes (bio-leaching); where the physical and chemical base of degradation of sulphidic structures is identical with the methods of the regeneration of desulphurization sorbents mentioned above.

The principle of all the mentioned methods is the process of sulphides oxidation with the utilization of various methods of catalysis. In the process of thermic regeneration is the oxidising reaction catalysed by the thermic energy, at pressure leaching by the pressure and temperature.

The aim of this paper is to testify the biological-chemical method as a new method of sorbents regeneration, utilising the catalytic effect of the metabolism of an acidophilous bacteria - Thiobacillus ferrooxidans, oxidising the sulphate and iron?.

The bio-leaching of this product leads to the biologicochemical degradation of amortised layers located on the surface, which is accompanied by the extraction of $\mathrm{Zn}$ and Fe to the leach.

The regenerated sample contained the franklinite, addition of magnetite, metal zinc and the rest of wurtzite, which during the observed period manifested itself as refractory mineral and a longer period or the change of electrochemical conditions of leaching should be needed for its destruction ${ }^{\mathbf{1 0}}$.

With reference to the reality, the effectivity (the sorption capacity) of sorbents is directly connected with the sizes of their surfaces and inversely with the particles sizes the changes of these parameter were also studied. The process of biological-chemical regeneration caused intense changes in the adsorption surface of sorbents, it has changed from the value of $2.8245 \mathrm{~m}^{2} \cdot \mathrm{g}^{-1}$ at amortised sample to the value of
Table 1. Comparison of the selected physical and chemical charakteristics of the zinc ferrite sorbents before and after biological and chemical regeneration

\begin{tabular}{|l|c|c|}
\hline SAMPLE & $\begin{array}{c}\text { Specific } \\
\text { surface } \\
{ }_{\mathrm{A}} \text { “ }\left[\mathrm{m}^{2} \mathrm{~g}^{-1}\right]\end{array}$ & $\begin{array}{c}\text { Average of } \\
\text { particles } \\
\mathrm{d}_{50}[\mu \mathrm{m}]\end{array}$ \\
\hline Primary sorbent & 2.6 & 4.77 \\
Pasivated sorbent & 2.8 & 9.10 \\
$\begin{array}{l}\text { REGENERISED } \\
\text { SORBENT }\end{array}$ & 6.2 & 2.19 \\
\hline
\end{tabular}

„" "(Surfaces factor "f") : $f=S_{\text {Ads. }} / S_{\text {Geom. }}$.

$6.2543 \mathrm{~m}^{2} \cdot \mathrm{g}^{-1}$ at the regenerated sample (Table 1.). The expressive change was also registered at the distribution of the particles sizes. The value of mean particle diameter has decreased from the value of $9.1 \mathrm{~mm}$ at amortised sorbent to $2.19 \mathrm{~mm}$ at the regenerated sorbents.

\section{CONCLUSIONS}

The presented results confirm the possibility of utilization of the biological-chemical method as:

1) the main operation of the processing and complex use of waste brown sludge from aluminium production,

2) the basic process of hematite pigment production from metallurgical lead-matte-based waste,

3) a new regeneration method of desulphurization sorbents based on zinc ferrite. The big advantage of this process in comparison with conventional regeneration methods is the lowering of the temperature of leaching from $500^{\circ} \mathrm{C}$ to $30^{\circ} \mathrm{C}$.

However, in metallurgy there is a wide range of other options for the use of bio-chemical processes, e.g. ferricsulphate-based leaching agent regeneration (and pickling baths) and it is possible to assume that much bigger part of options has not been researched yet.

\section{ACKNOWLEDGEMENT}

This work was supported by the Slovak Research and Development Agency under the contract No. APVV-51027705 and. Grant Agency Project VEGA No. 1/3343/06.

\section{LITERATURE CITED}

1. Varheghyi, Gy. et al. "Removving of the heavy metals by bacteria" Bányaszati és koházatin lapok/Mining and Metallurgical letters 1973, pp. 9, 415 - 419.

2. Kuhnhalmi, G. "Red sludge from production of the $\mathrm{Al}_{2} \mathrm{O}_{3}-$ Ecological problem", Acta Metallurgica, 4, special Issue, 1/1998, pp. 145 - 149.

3. Kafka, R. "Environmental strategy of ZSNP group”. In: Proceeding VIII. Al symposium, Donovaly 1997.

4. Kušnierová, M. \& Styriaková, I. "Influence of the biological and chemical factors for the composition of red sludge". In: Nové trendy v úpravníctví /New trends in the Mineral Processing, VŠB Ostrava, 1995; pp 224 - 227.

5. Kušnierová, M. \& Vašková, H. ”Biological and chemical treatment of the waste sludge from the production of Aluminium". In: Recyklace odpadu / Recycling of Waste IV., VŠB Ostrava, 2000; pp $27-30$.

6. Krištofová, D., Cablík, V., Fečko, P. \& Kušnierová, M. "Behavior of lead matte at the biological leaching". Hutnícke listy / Metallurgical letters 2001, pp. 6 - 7, $95-98$. 
7. Krishan, G.N., Tong, G.T., Lamoreaux, R.H., Brittain, R.D. \& Wood, B.J. "A study of sufate formation During Regeneration f Zinc Ferrite Sorbents". In :Proceedings, Fift Annual Contractorś Meeting on Contaminant Contol in Hot Coal-Derived Gas Streams.,U.S. Department of Energy/ METC, Morgantown, W.V.,DOE/METC-85/6025, pp 6 - 18.

8. Sasaoka, E., Hatori, M., Sada, N. \& Uddin, A. "Role of $\mathrm{H}_{2} \mathrm{O}$ in Oxidative Regeneration of $\mathrm{ZnS}$ Formed from High - Temperature Desulphurization $\mathrm{ZnO}$ Sorbent", Ind.Eng.Chem.Res. 2000, 39, 3844 - 3848.

9. "Bergy's Manual of Determinative Bacteriology", 8thed. Buchanan, R.E. \& Bigons, N.E., Baltimore.

10. Baret, J., Hughes, M.N., Karavajko, G.I. \& Spencer, P.A., Metal extraction by bacterial oxidation of minerals, Eois Horwood, New York, 1996, p. 186. 